Original Research

\title{
The Effect of Basic Life Support Course on Community Knowledge Level
}

\author{
I Kadek Artawan ${ }^{1}$, Yupin Aungsuroch ${ }^{2}$, I Gede Juanamasta 3 , I Made Sukma Wijaya ${ }^{1}$, \\ \& Komang Agus Jerry Widyanata ${ }^{1}$ \\ ${ }^{1}$ STIKES Kesdam IX/Udayana, Denpasar, Indonesia \\ ${ }^{2}$ Chulalongkorn University, Bangkok, Thailand \\ ${ }^{3}$ STIKES Wira Medika Bali, Denpasar, Indonesia
}

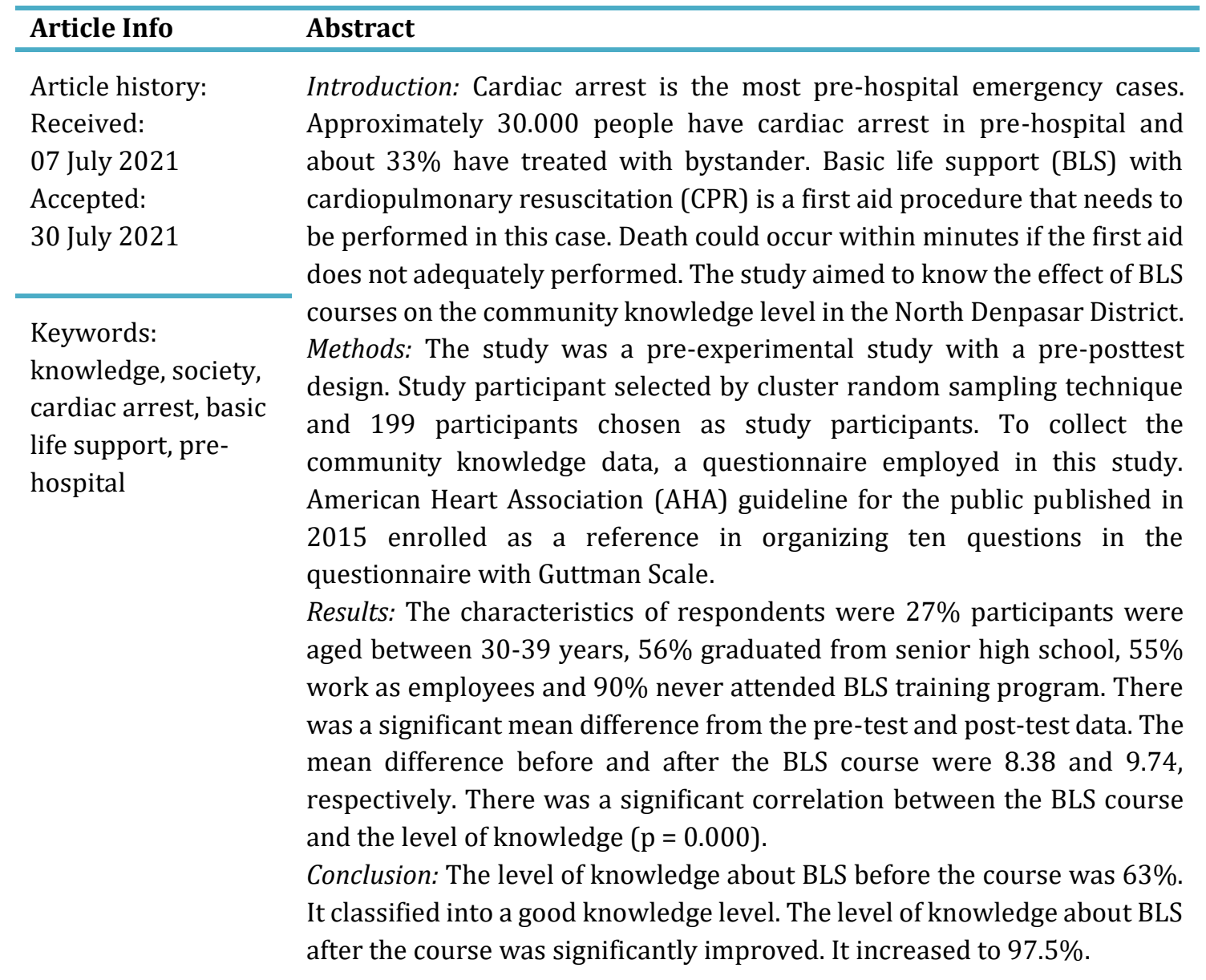

*Corresponding Author:

e-mail: yaungsuroch@gmail.com

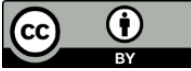

This work is licensed under a Creative Commons Attribution 4.0 International License. 


\section{INTRODUCTION}

Cardiac arrest recognizes as an emergency case that requires fast professional help. Basic life support (BLS) with cardiopulmonary resuscitation (CPR) is a first aid procedure that needs to be performed in this case. Death could occur within minutes if the first aid does not adequately performed [1].

A survey conducted by the Centers for Disease Control and Prevention (CDC) in the United States of America had found 31,689 heart attack cases in the last five years (20052010). Around thirty-three percent of these cases received CPR by the bystanders, $3.7 \%$ of those CPR procedures assisted by an automated external defibrillator (AED) [2]. In addition, a study done by Sasson et al also revealed that cardiac arrest had been identified as the primary cause of $15 \%$ of approximately 360,000 heart attack cases found in the out-of-hospital setting [3]. The annual prevalence of cardiac arrest in Indonesia remains unclear. However, the risk of heart diseases had reached a percentage of 7.2\%/year [4]. The number of cardiac arrest cases in Bali Province, particularly in the City of Denpasar, also did not well-identified. Nevertheless, the prevalence of coronary heart disease and heart failure in 2013 was $0.7 \%$ and $0.1 \%$, respectively. These heart diseases highly potential trigger heart attack and cardiac arrest [5].

Cardiopulmonary resuscitation is a significant part of BLS in which helps the heart restore heart function and spontaneous blood circulation. BLS should be performed as quickly as possible by the bystander whenever it happened to increase the life survival [6], [7]. BLS applied the concept of chain of survival that composed of: early identification and access, CPR, early defibrillation by using AED, and early advanced life support [6], [7]. Therefore, BLS courses or training are vital to improving the community knowledge and skill as the potential first responder on cardiac arrest cases [7].

According to the shred of evidence, we concluded that cardiac arrest is a sudden situation in which the heart loses its function that causes inadequate supply of oxygen to the vital organs and could lead to death without proper medical help. Denpasar City has a high potential for cardiac arrest incidents in the out-of-hospital setting. Adequate aids from the first responder play a vital role in increasing the chance of life survival of the cardiac arrest victim. Hence, the study aimed to know the effect of BLS courses on the community knowledge level in the North Denpasar District.

\section{METHODS}

This was a pre-experimental study with a preposttest design. Study participant selected by cluster random sampling technique, a method of location-based-sample selection. This type of sample selection commonly preferred due to the broad scope of study variables with limited area and cost of the study. Inclusion criteria employed in this study were (1) living in North Denpasar District, listed as a member of banjar (traditional administrative border of the area in Bali), and had decent literacy skills. According to the inclusion and exclusion criteria, 199 participants chosen as study participants. All of participans follow a course and had pre-posttest undergo pre-test 
and post-test during the course. This study was conducted in five days on January 25th29th, 2016, in Peguyangan and Peguyangan Kaja Village, North Denpasar District. To collect the community knowledge data, a questionnaire employed in this study. American Heart Association (AHA) guideline for the public published in 2015 enrolled as a reference in organizing ten questions in the questionnaire. Guttman Scale (correct and wrong scale) applied in the questionnaire. Validity test using Pearson product moment test and reliability test using Cronbach alpha formula. The validity test found that ten items were valid with a value of $<0.05$ and Cronbach's alpha value of 0.73 which stated high reliability. The level of knowledge in this study classified into good (76-100\%), moderate $(56-75 \%)$, and poor $(<56 \%)$. This study had been permitted by Puskesmas and permission from North Denpasar Disrict on January 25, 2016.

\section{RESULTS}

This study conducted in North Denpasar, a district with a high population density in Denpasar City area. North Denpasar covers 11 villages under its area, with the merchant, private sector worker, civil servant, and farmer as the top occupation. This study was only conducted in two villages in the North Denpasar District due to the limited duration and cost to conduct a wide-scale of study. Cardiac arrest could happen to anyone, anytime, and everywhere. Hence, community member is the most potential first responder during the cardiac arrest case. A proper BLS performed by the first responder highly potential in saving the life of the victim.
Table 1 reveals that 54 (27\%) and 46 (23\%) participants were aged between 30-39 and 20-29 years old, respectively. This result also indicated that the majority of participants were in productive age (20-50 years old).

Table 1 shows that the majority of participant was graduated from Junior High School/Vocational High School (113 participants; $56.5 \%$ ). Only four participants (2\%) did not finished education at the elementary school level.

Table 1 shows that the majority of participants were workers in the private sector (103 participants; 52\%). It also presented that $37.5 \%$ of participants were working as farmers, housewives, labor, and merchant.

Table 1 shows that the majority of participants never been exposed to BLS courses or classes (173 participants; 87\%) during the study. While, Table 5.5 reveals that the majority of the knowledge level before the BLS course was (137 participants; 69\%). Only 11 participants $(5.5 \%)$ had a low knowledge level.

Table 2 shows that the majority of participant had good knowladge level (137 participants; 69\%). Only eleven participants (11\%) had poor knowledge level.

Table 3 shows that 194 (97.5\%), 3 (1.5\%), and 2 (1\%) participants had a good, moderate, and poor level of knowledge, respectively.

The proportion and frequency analysis of the knowledge level, demography participant's characteristic, and its correlation conducted by a crosstab or chisquare analysis. Chi-square analysis with $p \leq 0.05$ done to compare and identify 
the correlation between the knowledge level and participant's characteristic.

Table 4 reveals that participant who aged between 30-39 years (72\%) had a good level of knowledge. Twenty-eight (61\%) and 32 participants (74\%) aged between 20-29 and 40-49 years old, respectively, also had a good level of knowledge. Statistical analysis revealed no significant correlation found between the level of knowledge and age $(p=$ 0.509).

Table 5 presents the analysis result of knowledge level according to the educational background. Eighty-one participants (72\%) who were graduated from Senior High School/Vocational High School had a good level of knowledge. Statistical test result revealed no significant correlation between the level of knowledge and educational background $(\mathrm{p}=0.779)$.

Table 6 shows that 73 participants (71\%) who were working as a worker in private sectors had a good level of knowledge of BLS. Statistical analysis did not show a significant correlation between the level of knowledge and occupation ( $\mathrm{p}=0.103)$.

Table 7 presents the statistical analysis of knowledge level according to exposure to the BLS course. It showed that 120 participants (69\%) who never been exposed to the BLS course had a good level of knowledge. The correlation test showed that there was no significant correlation between the level of knowledge with the exposure to the BLS course $(\mathrm{p}=0.353)$.

The data of pre-test and post-test before and after the course analyzed to identify the course's effect. The mean difference in the pre-test and post-test data revealed a correlation of the course with the level of knowledge. The analysis result reveals in Table 8. Analysis revealed a significant mean difference from the pre-test and post-test data. The mean difference before and after the BLS course were 8.38 and 9.74, respectively. A paired sample t-test then conducted to know the correlation between the study variables. A normality test conducted before the correlation test due to the employment of the ratio scale on the study variables. Kolmogorov Smirnov enrolled as the normality test because of the number of study participants > 50. Normality test showed significant results on the pre-test and post-test data with a pvalue of 0.000 . This result indicated that the data did not normally distribute. Thus, the non-parametric paired sample t-test (Wilcoxon) conducted to analyze the correlation. This test aimed to know the effect of the BLS course on the level of knowledge through the pre-test and post-test mean difference. Table 8 shows that the p-value obtained from the test was 0.000, p <0.05. This result indicated that the Ho was refused and $\mathrm{Ha}$ accepted. Therefore, there was a significant correlation between the BLS course and the level of knowledge ( $p=0.000)$. 
Table 1

Participant's Characteristic

\begin{tabular}{lcc}
\hline \multicolumn{1}{c}{ Participant's Characteristic } & $\mathbf{n}$ & $\mathbf{\%}$ \\
\hline Age (Years) & 46 & 23 \\
$20-29$ & 54 & 27 \\
$30-39$ & 43 & 22 \\
$40-49$ & 44 & 22 \\
$50-59$ & 12 & 6 \\
$60-69$ & & \\
\hline Educational Background & 4 & 2 \\
Did not finish elementary school education & 14 & 7 \\
Elementary School & 34 & 17 \\
Junior High School & 113 & 56.5 \\
Senior High School/Vocational High School & 31 & 16 \\
University (Bachelor Degree) & 3 & 1.5 \\
University (Master/Doctoral Degree) & & \\
\hline Occupation & 18 & 9 \\
Civil servant & 103 & 52 \\
Private sector worker & 2 & 1 \\
Teacher/Lecturer & 1 & 0.5 \\
Health professional (nurse, midwife, doctor, etc.) & 75 & 37.5 \\
Others (farmer, housewife, labor, and merchant) & & 13 \\
\hline Exposure to BLS Course/Class & 26 & 87 \\
Had been exposed to BLS course/class & 173 & $\mathbf{1 0 0}$ \\
Never been exposed to BLS course/class & $\mathbf{1 9 9}$ & \\
\hline
\end{tabular}

Table 2

Frequency Distribution before the BLS Course

\begin{tabular}{lccc}
\hline & Knowledge Level & n & \% \\
\hline Poor & & 11 & 5.5 \\
Moderate & & 51 & 25.5 \\
Good & Total & 137 & 69 \\
\hline & & $\mathbf{1 9 9}$ & $\mathbf{1 0 0}$ \\
\hline
\end{tabular}

Table 3

Frequency Distribution before the BLS Course

\begin{tabular}{lccc}
\hline & Knowledge Level & $\mathbf{n}$ & $\mathbf{\%}$ \\
\hline Poor & & 2 & 1 \\
Moderate & & 3 & 1.5 \\
Good & Total & 194 & 97.5 \\
\hline & & $\mathbf{1 9 9}$ & $\mathbf{1 0 0}$ \\
\hline
\end{tabular}

Table 4

Knowledge Level According to Age

\begin{tabular}{cccccccccc}
\hline \multirow{2}{*}{ Age } & \multicolumn{4}{c}{ Knowledge Level } & \multicolumn{4}{c}{ Total } & \multirow{2}{*}{$\boldsymbol{p}$} \\
\cline { 2 - 9 } & Poor & \% & Moderate & \% & Good & \% & $\mathbf{N}$ & \% & \\
\hline $20-29$ & 2 & 4 & 16 & 35 & 28 & 61 & 46 & 100 & 0.509 \\
$30-39$ & 2 & 4 & 13 & 24 & 39 & 72 & 54 & 100 & \\
$40-49$ & 2 & 5 & 9 & 21 & 32 & 74 & 43 & 100 & \\
$50-59$ & 5 & 11 & 9 & 20 & 30 & 69 & 44 & 100 & \\
$60-69$ & 0 & 0 & 4 & 33 & 8 & 67 & 12 & 100 & \\
\hline Total & $\mathbf{1 1}$ & & $\mathbf{5 1}$ & & $\mathbf{1 3 7}$ & & $\mathbf{1 9 9}$ & $\mathbf{1 0 0}$ & \\
\hline
\end{tabular}


Table 5

Knowledge Level According to Educational Background

\begin{tabular}{|c|c|c|c|c|c|c|c|c|c|}
\hline \multirow{2}{*}{$\begin{array}{l}\text { Educational } \\
\text { Background }\end{array}$} & \multicolumn{6}{|c|}{ Knowledge Level } & \multicolumn{2}{|c|}{ Total } & \multirow[t]{2}{*}{$p$} \\
\hline & Poor & $\%$ & Moderate & $\%$ & Good & $\%$ & $\mathbf{N}$ & $\%$ & \\
\hline $\begin{array}{l}\text { Did not finish } \\
\text { elementary school } \\
\text { education }\end{array}$ & 0 & 0 & 1 & 25 & 3 & 75 & 4 & 100 & 0.779 \\
\hline Elementary School & 0 & 0 & 3 & 21.4 & 11 & 78.6 & 14 & 100 & \\
\hline Junior High School & 2 & 6 & 10 & 29 & 22 & 65 & 34 & 100 & \\
\hline $\begin{array}{l}\text { Senior High } \\
\text { School/Vocational } \\
\text { High School }\end{array}$ & 6 & 5 & 26 & 23 & 81 & 72 & 113 & 100 & \\
\hline $\begin{array}{l}\text { University } \\
\text { (Bachelor Degree) }\end{array}$ & 3 & 10 & 11 & 35 & 17 & 55 & 31 & 100 & \\
\hline $\begin{array}{l}\text { University } \\
\text { (Master/Doctoral } \\
\text { Degree) }\end{array}$ & 0 & 0 & 0 & 0 & 3 & 100 & 3 & 100 & \\
\hline Total & 11 & & 51 & & 137 & & 199 & 100 & \\
\hline
\end{tabular}

Table 6

Knowledge Level According to Occupation

\begin{tabular}{|c|c|c|c|c|c|c|c|c|c|}
\hline \multirow[t]{2}{*}{ Occupation } & \multicolumn{6}{|c|}{ Knowledge Level } & \multicolumn{2}{|c|}{ Total } & \multirow[t]{2}{*}{$p$} \\
\hline & Poor & $\%$ & Moderate & $\%$ & Good & $\%$ & $\mathbf{N}$ & $\%$ & \\
\hline Civil Servant & 4 & 22 & 6 & 33 & 8 & 45 & 18 & 100 & 0.103 \\
\hline Private Sector & 4 & 4 & 26 & 25 & 73 & 71 & 103 & 100 & \\
\hline Worker & & & & & & & & & \\
\hline Teacher/Lecturer & 0 & 0 & 1 & 50 & 1 & 50 & 2 & 100 & \\
\hline Health & 0 & 0 & 0 & 0 & 1 & 100 & 1 & 100 & \\
\hline $\begin{array}{l}\text { Professional } \\
\text { (Nurse, Midwive, } \\
\text { Doctor) }\end{array}$ & & & & & & & & & \\
\hline Others & 3 & 4 & 18 & 24 & 54 & 72 & 75 & 100 & \\
\hline Civil Servant & 4 & 22 & 6 & 33 & 8 & 45 & 18 & 100 & \\
\hline Total & 11 & & 51 & & 137 & & 199 & 100 & \\
\hline
\end{tabular}

Table 7

Knowledge Level According to Exposure to BLS course

\begin{tabular}{lccccccccc}
\hline Occupation & \multicolumn{3}{c}{ Knowledge Level } & \multicolumn{3}{c}{ Total } & $\boldsymbol{p}$ \\
\cline { 2 - 9 } & Poor & \% & Moderate & \% & Good & \% & N & \% & \\
\hline $\begin{array}{l}\text { Had been exposed } \\
\text { to BLS course }\end{array}$ & 3 & 11.5 & 6 & 23 & 17 & 65.5 & 26 & 100 & 0.353 \\
$\begin{array}{l}\text { Never been } \\
\text { exposed to BLS } \\
\text { course }\end{array}$ & 8 & 5 & 45 & 26 & 120 & 69 & 173 & 100 \\
\hline \multicolumn{1}{c}{ Total } & $\mathbf{1 1}$ & & $\mathbf{5 1}$ & & $\mathbf{1 3 7}$ & $\mathbf{1 9 9}$ & $\mathbf{1 0 0}$ \\
\hline
\end{tabular}

Table 8

The Effect of BLS Course on the Knowledge Level about BLS

\begin{tabular}{ccccc}
\hline Variable & Mean & N & St dev & p-value \\
\hline Pre-test & 8.38 & 199 & 1.76 & 0.000 \\
Post-test & 9.74 & 199 & & \\
\hline
\end{tabular}




\section{DISCUSSION}

\section{Knowledge Level According to the Participant's Characteristic}

This study found that 54 (28\%) and 46 (23\%) participants were aged between 30-39 and 20-29 years old, respectively. Knowledge level analysis according to the age found that 31 participants who aged between 30-39 years old (61\%) had a good level of knowledge. No significant correlation between the level of knowledge and age found in this study $(\mathrm{p}=0.509)$. World Health Organization (WHO) stated that individuals who aged between 20-40 years old classified into early adult or young adult group. Dariyo added that the young adult group (20-40 years old) commonly had higher responsibility and role, better skill in accepting information, and processing them in optimal phase [8]. Potter (2005) also added that individuals with young age relatively easier in accepting or learning new knowledge. Also, no impairment of cognitive function happened at a young age. Dariyo also stated that the young age population commonly capable of solving complex problems with abstract, logical, and rational thinking capacity. In addition, the middleaged population also rarely experiences decreased cognitive function in memorizing information [8]. This finding was parallel with several previous studies related to the community knowledge of BLS. Erawati found that the young-adult age group had a better level of knowledge due to their active participation in gaining knowledge from various sources and the socialization process [9]. They also tended to be more enthusiastic in learning and participating in the study. Dahlan, Kummat, and Onibala also supported this finding. They found that the BLS knowledge of the young-adult age population was better than other age groups [10]. Their good memorizing skill may play a vital role in this finding. The body function in young-adult age had already fully developed with more complex cognitive function [11].

Young-adult age considered the most productive period with well-developed physical and cognitive functions. Young age is associated with good skill in learning new things from various sources. Statistical analysis revealed no significant correlation between the level of knowledge and age. A study by Hanifah also found a similar finding [12]. They also found no direct correlation between the level of knowledge and age. Educational background, type of occupation, and technology and information (internet) also could contribute to the level of knowledge. This study also found that middleaged participants had a good level of knowledge. Therefore, this finding also indicated that the young-aged and middleaged population had a good level of knowledge. The age of 20-60 years old is considered a productive period in life. Cognitive disorders are also rarely found in this period. Hence, these age range are still appropriate in accepting and learning about new information.

The recent study found that 113 participants (56.5\%) were graduated from Senior High School/Vocational High School. Eighty-one (67.2\%) of them had a good level of knowledge of BLS, only six participants $(5 \%)$ had a low level of knowledge of BLS. 
Statistical analysis between the educational background and level of knowledge found a pvalue of 0.779 , which indicated no significant correlation between the level of knowledge and educational background. Education is guidance administered to understand a thing [13]. High educational background creates the acceptance and adjustment process of values easier [14]. Hanifah also supported this statement. In her study, she stated that a low level of knowledge inhibits knowledge and individual attitude development to novel values introduced to the society [12]. Notoatmodjo also explained that knowledge associated with educational background [14]. This statement was parallel with the current finding. Further investigation also required to identify the association between the level of knowledge and the educational background.

Without taking into account the age and background, BLS are required for all layers in the community. The purpose of formal education was to improve the learning skills. Hence, the level and type of education would generate a change in the knowledge [15]. BLS course was necessary to be administered at a young age to gain knowledge and skill in performing first aid for cardiac arrest victims adequately. A study by Jasna found a positive attitude toward the BLS course among the second-grade elementary school students [12]. This study also revealed that BLS course made the study participants more confident in performing BLS. It also helped them manage their fear in performing BLS and these outcomes finally would improve the survival rate of cardiac arrest victims.

Results showed that 103 participants were working in the private sector (52\%).
Seventy-three of them (71\%) had a good level of knowledge. Statistical analysis showed no significant correlation between the level of knowledge and occupation $(\mathrm{p}=0.103)$. Occupation defined as attempts conducted to make an everyday living [15]. Ambada in his study about public knowledge about the antibiotic use, stated that individual with higher income was more capable providing adequate facilities for living [16]. Higher income usually came from those who were working as teachers or civil servants. However, the statistical analysis did not show a significant correlation between the occupation and level of knowledge. This finding supported by a study done by Ambada about public knowledge about antibiotic use [16] and Sinaga about the knowledge about hypertension [17].

The distribution of the income might play a role that affected the finding. Most participants could designate their salary to facilities that did not support the knowledge about BLS. Participants also could be prioritized other families need to be met first. The majority of the participants were a worker in private sectors. They had higher work pressure and highly focused on their job. It also makes them impossible to diverse their focus to learn about BLS. Each occupation also had a different amount of income that may could not adequately meet their needs. It made them more careful in spending their income to meet everything they need in making a living.

Eighty-seven (87\%) of the participants stated never been exposed to BLS courses. The level of knowledge analysis according to the exposure to BLS courses had shown that 
120 participants (69\%) had a good level of knowledge. Statistical analysis also revealed no significant correlation between the level of knowledge and exposure to BLS courses $(\mathrm{p}=$ 0.353). A course is a type of non-formal education that manages a learning process about knowledge or skill. Participating in a course signifies gaining experience related to a topic. Experience is profoundly affected by age and educational background. Higher educational background and older age produced a broader range of experience [18].

This study did not find a correlation between knowledge and exposure to BLS course. Participants who never been exposed to the BLS course also had a good level of knowledge. Other sources of information of BLS might highly affect their knowledge, especially from printed or electronic platforms. A study by Erawati revealed that the public tended to find BLS information on the electronic platform (48.8\%), from other people (29.3\%), books (13.8\%), and printed media (8.1\%) [9].

Several studies provided evidence that knowledge about BLS could be supported by exposure to the content in electronic platforms. Nafa et al. found knowledge about proper CPR procedures correlated with health education exposure from health television programs (non-drama programs), internet, and newspaper [19]. 96\% of participants in their study learned CPR techniques effectively from television programs [20].

The rapid development of information technology impacts convenient access to various information. The community member could easily access everything from the internet. Television is no longer only found in the house, but also could be accessed through mobile phone. Nowadays, mobile phone contains many applications to view broadcast not only from a country but also many foreign countries. These facts indicated that having a mobile phone was a ubiquitous phenomenon in the community. The ownership of the mobile phone did not significantly affect by their ages, educational background, and occupation.

\section{Community Knowledge Level before BLS Course}

The current study showed that 137 participants (69\%) had a good level of knowledge, only 11 participants (5.5\%) had a low level of knowledge. A study by Erawati also found that the community in South Jakarta had a good level of knowledge of BLS. This study employed a similar number of population with the current study [9].

Community in the urban city tended to gain broader access to information. Broader access to information linked to a higher level of knowledge [18] A study done by Erawati (2015) [9] had found that the community gained more information about BLS from the electronic platform $(48,8 \%)$. They found that $96 \%$ of the community was learning about CPR effectively from information provided on the television [15]. They found that the level of knowledge about CPR correlated with exposure to health programs aired on television [19]. This study did not evaluate the sources of BLS information in the study population. Future studies required to identify the type of BLS information sources. Hence, the factors that affected the level of 
knowledge could be specifically identified [19], [20].

The study questionnaire employed the concept of BLS from AHA that published in 2015. BLS procedures performed by health professionals had distinctive characteristics from the BLS procedure for the community. Public or untrained personnel is known as bystanders/lay rescuers. The main action required to do by them is CPR or chest compression [21]. Further, the BLS guideline published by AHA 2010 and 2015 stated that if community members found an unconscious person, they need to contact the health professional of health provider as soon as possible or directly perform CPR with or without ventilation. According to this concept, the questionnaire enrolled in this study had organized to be easily understood by the community. It also had tested for its reliability and validity with the value of $\alpha$ and alpha Cronbach $<0,05$ and $0.730 \%$, respectively.

\section{Community Knowledge Level After BLS Course}

After the administration of the BLS course, the current study found that 194 participants $(97,5 \%), 3$ participants $(1,5 \%)$, and 2 participants (1\%) had good, moderate, and poor knowledge about BLS, respectively. Community knowledge was assessed through a questionnaire. This questionnaire composed of ten relatively easy questions that possible to be answered by only relied on logical skills. The employment of this questionnaire might affect the level of knowledge found in this study [15]. He said that knowledge could be gained in many ways: trial and error, authority, and personal experience. Participants could utilize the trial and error method or use their logical skills in answering the questions in the questionnaire. The trial and error method is a traditional effort in gaining knowledge by using a broad range of possibilities in solving a problem. If a possibility did not work, another possibility would be tried until the problem is solved [18].

These findings only enclosed the community's understanding and level of knowledge about BLS. Further studies required to investigate community attitude and skill in performing BLS. A study found a significant correlation between knowledge level and skill in performing BLS [22]. These findings indicated that further studies require to be conducted as a sustainable evaluation of community knowledge about BLS and scientific evidence in organizing sustainable future health courses in the community setting. We expect community resilience in performing fast and proper BLS procedures to cardiac arrest cases, especially in the out-ofhospital setting. Consequently, the survival rate increase and the morbidity because of the cardiac arrest decrease [22].

BLS information was essential for all layers of the community. In line with this statement, BLS needed to be understood at an early age, even by school-aged children. Although information about BLS could easily be accessed through various electronic platforms, the BLS course remained significant to train the community member in delivering proper BLS as written on the international guideline of BLS. Good level of knowledge correlated with good skill in 
performing BLS in the out-of-hospital setting [8].

\section{The Effect of BLS Course on}

\section{Community Knowledge Level}

\section{Improvement}

Wilcoxon test revealed that the value of Sig. (2-tailed) was $0.000,>0.05$. This value indicated that Ho refused and $\mathrm{Ha}$ accepted. Hence, there was a significant difference in the pre-test and post-test values after the BLS course. The mean difference happened due to knowledge improvement after the BLS course. Health education defined as a learning method that involving the process of growing, developing, changing, and refining on individual, group, and community levels [23]. Several interactions and mechanisms in the learning process originate behavioral or skillset changes. Notoatmodjo (2010) [14] also stated that health education or health promotion is an effort to advertise, disseminate, introduce, or trade health to make the community accept or purchase it. This definition refers to behavioral acceptance and adoption of a healthy lifestyle at the community level. Behavioral change happens following the increase of knowledge or understanding of an issue through the learning or education process. A characteristic of the learning or education process is producing change that could be observed from the output after the learning process or education. The change that happened in this study was the knowledge level or cognitive domain change in understanding BLS. This finding was parallel with a study conducted by Fitriani that had found significant output improvement on the cognitive domain in understanding BLS [23].

Cognitive change in this study only evaluated by the level of knowledge in understanding and knowing process of BLS. According to the Bloom Taxonomy by Bloom, Englehart, Furst, Hill, and Krathwohl in 1956, the level of cognitive or knowledge consisted of knowing, comprehensive, application, analysis, synthesis, and evaluation [24]. The knowledge level evaluated in this study mainly focused on memorizing and understanding information on the course. Memorizing defined as an attempt to revive the information learned. Recalling is a process covered in this level. Recalling is defined as the process of memorizing specific things from all information learned in a course or education. This level considered the most low level of knowledge [18]. Understanding defined as skills in explaining and interpreting certain things appropriately [18]. Community knowledge successfully improved through the course sessions. This finding provided scientific evidence for the implementation of community health courses in improving the knowledge level. Furthermore, a sustainable health course promotes the level of understanding of the implementation of BLS. It helps to level their skill up, from only knowing and understanding to implementing adequate BLS on cardiac arrest cases. Hence, a comprehensive health course is significant in improving community health status, especially in performing BLS.

\section{CONCLUSION}

The demography characteristic of study participants were: aged between $30-39$ years 
old or considered in productive age group (27\%), graduated from Senior High School/Vocational High School (56.5\%), working in the private sector (52\%), and never been exposed to BLS course (87\%).

The level of knowledge about BLS before the course was $63 \%$. It classified into a good knowledge level.

The level of knowledge about BLS after the course was significantly improved. It increased to $97.5 \%$.

Statistical analysis revealed a significant effect of BLS courses on the knowledge level of the community, with the p-value of 0.000 .

\section{REFERNCES}

[1] C. Vaillancourt, I. G. Stiell, and Canadian Cardiovascular Outcomes Research Team, "Cardiac arrest care and emergency medical services in Canada.," Can. J. Cardiol., vol. 20, no. 11, pp. 108190, Sep. 2004, [Online]. Available: http://www.ncbi.nlm.nih.gov/pubmed/ 15457303.

[2] B. McNally et al., "Out-of-hospital cardiac arrest surveillance --- Cardiac Arrest Registry to Enhance Survival (CARES), United States, October 1, 2005-December 31, 2010.," MMWR. Surveill. Summ., vol. 60, no. 8, pp. 1-19, 2011, [Online].

Available: http://www.ncbi.nlm.nih.gov/pubmed/ 21796098.

[3] C. Sasson et al., "Increasing Cardiopulmonary Resuscitation Provision in Communities With Low Bystander Cardiopulmonary Resuscitation Rates," Circulation, vol.
127, no. 12 , pp. 1342-1350, Mar. 2013, doi: 10.1161/CIR.0b013e318288b4dd.

[4] Badan Penelitian dan Pengembangan Kesehatan (BPPK) RI, Riset Kesehatan Dasar (Riskesdas) 2007. Jakarta: Badan Penelitian dan Pengembangan Kesehatan (BPPK) RI, 2007.

[5] S. Pranata, Y. Fauziah, M. A. Budisuari, and I. Kusrini, Riset Kesehatan Dasar dalam Angka Provinsi Bali 2013. Jakarta: Badan Penelitian dan Pengembangan Kesehatan (BPPK) RI, 2013.

[6] A. Subagjo, Achyar, E. Ratnaningsih, T. Sugiman, A. Kosasih, and R. Agustinus, Buku Panduan Kursus Bantuan Hidup Jantung Dasar. Jakarta: Perhimpunan Dokter Spesialis Kardiovaskular Indonesia, 2011.

[7] T. Suharsono and D. Ningsih, Penatalaksanaan Henti Jantung Diluar Rumah Sakit. Malang: UMM Pres, 2008.

[8] A. Dariyo, Psikologi Perkembangan Dewasa Muda. Jakarta: PT.Gramedia Pustaka Utama, 2003.

[9] S. Erawati, Gambaran Pengetahuan Masyarakat Tentang Bantuan Hidup Dasar (BHD) di Kota Administrasi Jakarta Selatan. Skripsi. Jakarta: PSIK Fakultas Kedokteran dan Ilmu Kesehatan, Universitas Islam Negeri Syarif Hidayatullah, 2015.

[10] M. Dahlan, Statistik untuk Kedokteran dan Kesehatan: Deskriptif, Bivariat, dan Multivariat, Dilengkapi Aplikasi dengan Menggunakan SPSS. Edisi 5, 5th ed. Jakarta: Salemba Medika, 2011. 
[11] D. Papalia, H. L. Sterns, R. D. Feldman, and Camp, Adult Development asnd Aging.3rd. New York: MacGraw Hills, 2007.

[12] M. Hanifah, Hubungan Usia dan Tingkat Pendidikan dengan Pengetahuan Wanita Usia 20-50 Tahun tentang Periksa Payudara Sendiri (SADARI). Skripsi. Jakarta: Program Studi Pendidikan Dokter, Fakultas Kedokteran dan Ilmu Kesehatan, Universitas Islam Negeri Syarif Hidayatullah, 2010.

[13] Mubarak et al., Promosi Kesehatan. Yogyakarta: Graha Ilmu, 2007.

[14] S. Notoatmodjo, Pendidikan dan Perilaku Kesehatan. Jakarta: Rineka Cipta, 2003.

[15] S. Notoatmodjo, Promosi Kesehatan Teori dan Aplikasi. Edisi Revisi. Jakarta: Rineka Cipta, 2010.

[16] S. Ambada, Tingkat penegtahuan Masyarakat tentang Antibiotik pada Masyarakat Kecamatan X Kabupaten X, Universita. Surakarta, 2013.

[17] D. Sinaga, Gambaran Tinglat Pengetahuan tentang Hipertensi pada Masyarakat yang Merokok di RW 01 Kelurahan Pondok Cina, Beji, Depok, Skripsi. Jakarta: Fakultas Keperawatan Universitas Indonesia, 2012.

[18] A. Wawan and M. Dewi, Teori dan Pengukuran Pengetahuan, Sikap dan Perilaku. Yogyakarta: Nuha Medika, 2011.
[19] S. Nava, "The influence of the media on COPD patients\&rsquo; knowledge regarding cardiopulmonary resuscitation," Int. J. Chron. Obstruct. Pulmon. Dis., vol. Volume 3, pp. 295-300, Jun. 2008, doi: 10.2147/COPD.S1805.

[20] G. K. Jones, K. L. Brewer, and H. G. Garrison, "Public Expectations of Survival Following Cardiopulmonary Resuscitation," Acad. Emerg. Med., vol. 7, no. 1, pp. 48-53, Jan. 2000, doi: 10.1111/j.1553-2712.2000.tb01891.x.

[21] R. M. Merchant et al., "Part 1: Executive Summary: 2020 American Heart Association Guidelines for Cardiopulmonary Resuscitation and Emergency Cardiovascular Care," Circulation, vol.142, no. 16_suppl_2, Oct. 2020, doi: 10.1161/CIR.0000000000000918.

[22] U. Hasanah, Hubungan Tingkat Pengetahuan dengan Keterampilan Perawat dalam Melakukan Tindakan Bantuan Hidup Dasar (BHD) di RSUD Kabupaten Karanganyar. Skripsi. Surakarta: Program STudi S-1 Kepeerawatan, Stikes Kusuma Husada.

[23] S. Fitriani, Promosi Kesehatan. Yogyakarta: Graha Ilmu, 2011.

[24] C. Bon, "Cardiopulmonary Resuscitation (CPR)," 2014. https://emedicine.medscape.com/articl e/1344081-overview\#aw2aab6b2. 